\title{
Subject, Object, and Knowledge as First-Person
}

\author{
Maria Rosa Antognazza | ORCID: 0000-0002-5214-479X \\ Department of Philosophy, King's College London, London, UK \\ maria.rosa.antognazza@kcl.ac.uk
}

\begin{abstract}
This article tries to show that focusing on why and how subject and object are distinct is of key importance for understanding the nature of knowledge itself. It argues that: 1 ) cognition starts with an aliud which is present to a felt self in a way fundamentally different from one's own modes of being; 2) individual human knowledge in its paradigmatic form is essentially first-personal, that is, its object-directedness requires a built-in, implicit awareness of a 'self' that provides the unifying perspective from which the aliud is apprehended; 3 ) this is a first-order awareness which is crucially distinct from the second-order awareness which requires a reflexive cognitive act - a distinction which the author proposes to cash out in terms of 'first-person knowledge' versus 'self-knowledge.
\end{abstract}

\section{Keywords}

subject - object - self - first person - self-knowledge

This article builds on Michael Ayers's insightful phenomenological analysis of what it is like to be in direct cognitive contact with one's environment. More specifically, it attempts to develop and complement Ayers's claim that "primary knowledge" (that is, knowledge in its primary, basic, paradigmatic form) is "knowledge gained by being evidently, self-consciously, in direct cognitive contact with the object of knowledge" (2019, 63). Ayers rejects the widespread assumption that the best way to illuminate the notion of knowledge is to provide a definition or "analysis" that fits every case of what is commonly regarded as knowledge. He convincingly argues that we should instead start with the 
identification of the essential core of knowledge, that is, with the identification of what is central to knowledge in its primary, basic, strict sense. ${ }^{1}$

In this framework, my starting point is an account of how we arrive, in the first place, at the distinction between 'subject' and 'object'. This distinction is often simply presupposed without explanation. By contrast, I aim to show that focusing on why and how subject and object are distinct is of key importance for understanding the nature of knowledge itself. I will claim that the first phenomenological datum is the presence of something (whatever that is), and that this presence manifests itself in two phenomenologically distinct ways: some aspects are experienced (that is, lived, erlebt) as 'mine', others are experienced as 'other' (aliud) than me. The distinction between subject and object is grounded (I contend) in this phenomenology.

On this basis, I will argue that: 1) cognition starts with an aliud which is present to a felt self in a way fundamentally different from one's own modes of being; 2) individual human knowledge in its paradigmatic form is essentially first-personal, that is, its object-directedness requires a built-in, implicit awareness of a 'self' that provides the unifying perspective from which the aliud is apprehended;3) this is a first-order awareness which is crucially distinct from the second-order awareness which requires a reflexive cognitive act - a distinction which I propose to cash out in terms of 'first-person knowledge' versus 'self-knowledge'.

\section{The Distinction between Subject and Object}

\section{1}

\section{Two Different Ways of Being Present}

I follow Husserl in thinking that in an inquiry on knowledge one should go back zu den Sachen selbst, that is, to things themselves as they show or manifest themselves (1913, 6, "Wir wollen auf die 'Sachen selbst' zurückgehen.") The first phenomenological datum, I suggest, is the following: something is present. Note that no claim is made as to the nature of what is present. Likewise, no reference is made to a subject and/or an object, or (a fortiori) to their being or not being distinct. So far, this remark - something is present (whatever that is) - is merely a phenomenological observation which comes before any further metaphysical claim. This observation is nothing else, in my view, than the indubitable core of the Augustinian and the Cartesian cogito. That is, what

1 See Ayers 1991 (chap. 15, esp. 139-144 of the paperback, one-volume edition) and 2019 (esp. vi, $27,61-64,115,185,195)$. 
is first and foremost really indubitable in Augustine and Descartes's cogito is that aliquid est (rather than ergo sum) (Vanni Rovighi 1962, 112; see Maritain 1948, 148).

The second phenomenological observation is that this presence manifests itself in two, fundamentally distinct ways. Some aspects of what is present are phenomenologically experienced as modes of being of whatever it is that keeps together or unifies these modes of being. Such aspects of what is present are the affective and conative/appetitive states which are experienced (that is, lived, erlebt) as 'mine' - as being tired, feeling cold, wishing to warm up. Other aspects of what is present are not phenomenologically experienced as 'mine' in the same way in which, say, cold may be experienced as my feeling cold. In the phenomenology of the same unitary experience in which cold and white (the white of snow) are both present, feeling cold is experienced as my mode of being, while the white of snow is experienced as a mode of being of something other than me (intended here merely as a complex of affective and conative/appetitive states) feeling cold and wishing to warm up: I am feeling cold but I am not feeling white, although both cold and white are present. One can, on the other hand, feel an object (say, a snowball) as cold, but there is also in this case a phenomenal difference between feeling cold oneself (one's mode of being) and feeling an object as cold (the mode of being of an aliud). Likewise, if I am holding a heavy wooden box, I may feel tired, but not heavy, cubic, or wooden. Both tiredness and heaviness are present, but the first is experienced as my mode of being, the second as a mode of being of something 'other'.

These two fundamentally distinct ways in which something is present correspond, as far as I can see, to Thomas Reid's key distinction between "sensation" and "perception". "Sensation, and the perception of external objects by the senses," Reid notes, "though very different in their nature, have commonly been considered as one and the same thing" (Reid, Inquiry, chap. 6, sect. $\mathrm{xx}, 167$ ). The reason for this conflation, he continues, is the following (Reid, Inquiry, chap. 6 , sect. $\mathrm{xx}, 167-168)$ :

The same mode of expression is used to denote sensation and perception; and therefore we are apt to look upon them as things of the same nature. Thus, I feel a pain; I see a tree: the first denoteth a sensation, the last a perception. The grammatical analysis of both expressions is the same: for both consist of an active verb and an object. But, if we attend to the things signified by these expressions, we shall find, that in the first, the distinction between the act and the object is not real but grammatical; in the second, the distinction is not only grammatical but real. 
That is, 'sensations' are given, at least phenomenologically, as 'mine' (in Reid's terms, there is no real distinction between the act - feeling - and the object - pain), whereas 'perceptions' are phenomenologically given as referring to something 'other' (in Reid's terms, there is a real distinction between the act - seeing - and the object - a tree).

It seems to me that the fundamentally different way in which an affective or an appetitive state, as opposed to something else, is present, was clear also to Hume. Hume is often taken to deny that the 'self' or 'subject' is phenomenologically given because he denies that we find an impression of the self in the bundle of perceptions which constitutes what is present (Hume, Treatise I, IV, VI, ed. Selby-Bigge, 251-253). In fact, even Hume grants that the subject is primitively given but in a sui generis way, that is, as the subject of affective states (the 'passions'), as opposed to being given as an impression on a par with other impressions. After introducing in book I of the Treatise (devoted to "the Understanding") the famous metaphors of the bundle of perceptions and of the mind as "a kind of theatre" constituted only by "successive perceptions", Hume explicitly says that "we must distinguish betwixt personal identity, as it regards our thought and imagination, and as it regards our passions or the concern we take in ourselves. The first is our present subject" (Hume Treatise I, IV, VI, ed. Selby-Bigge, 3). That is, the 'bundle' and the 'theatre' metaphors regard the self as a cognitive subject (discussed in book I of the Treatise), not as the subject of affective states. The latter is the subject of book II of the Treatise, devoted to "the Passions" - and it is indeed through "the passions", and not via an "impression", that the "self, or that individual person, of whose actions and sentiments each of us is intimately conscious" is primitively given. (Hume Treatise I, IV, VI, ed. Selby-Bigge, 286; see also 317: "our consciousness gives us so lively a conception of our own person, that 'tis not possible to imagine, that any thing can in this particular go beyond it.")

In traditional scholastics terms, the difference between the two fundamental ways in which something is present corresponds to the distinction between two different kinds of unity: the real (or, we could say, 'ontological') unity of the complex of affective and conative/appetitive states which is labelled ' $I$, ${ }^{2}$ and the intentional unity between this ' $\mathrm{I}$ ' and something which is phenomenologically present as other than 'I'.

2 Scholastic terminology would call this kind of unity also 'physical', in the sense of pertaining to the physis, that is, to the nature of the subject. 


\subsection{Gaudeo, doleo, voleo, ergo sum}

In sum, the self is primitively given in its affective and in its conative/appetitive states. Rather than cogito ergo sum, we should say gaudeo, doleo, voleo, ergo sum. ${ }^{3}$ These affective and conative/appetitive states are qualitatively different from the kind of mental states in which something is phenomenologically given as 'other' than me, whatever the ontological status of this 'other'.

Spinoza's doctrine of conatus, central to his metaphysics in general and to his philosophical anthropology in particular, points (I contend) in the same direction, namely to the fact that an individual is primitively identified by its appetitive states, that is, in Spinoza's terms, by its conatus (i.e. tendency, striving) toward self-preservation. Indeed, for Spinoza, this appetite for selfpreservation is constitutive of any individual thing (Spinoza Ethics IIIp6):

Each thing, as far as it can by its own power, strives to persevere in its being;

and (Spinoza Ethics IIIp7)

the striving [conatus] by which each thing strives to persevere in its being is nothing but the actual essence of the thing.

This is not to deny that, for Spinoza, any perception of external things is accompanied by some sort of awareness of the affective states of one's body, or to deny that, in sense-perception, one's body is itself an object of perception. The point is that self-related sensations are still crucially different from otherrelated perceptions, as Spinoza clearly acknowledged. 4

This 'self', which is primitively felt as the subject of appetites, drives, affects - first of all, according to our generic animal nature, the drive or conatus toward self-preservation, and the attendant drives toward avoiding pain, seeking pleasure, and so on; then, according to our specifically rational animal nature, the higher affects and volitions -, is the subject which is aware of something 'other' than itself impinging, as it were, on itself.

\section{Knowledge as Intentional Presence}

These preliminary observations, I suggest, provide the basis on which an account of knowledge can be built. On this proposal, experiencing affects and

3 I take this point from Vanni Rovighi 1962, 112, where the Latin expressions are used.

4 See Renz 2019, 19 and Renz 2018, 161-167. 
appetites is the original and primitive way in which a sense of self is established. This affective and appetitive 'feeling oneself' is a condition of possibility of a cognitive relation but it does not yet establish a cognitive relation. It is only with the encounter with 'otherness', or with the perception of an aliud, that cognition begins - that is, cognition starts with something which is present to a felt self in a way fundamentally different from one's own mode of being. It is through this awareness of an aliud that the subject of affects and appetites becomes also a cognitive subject.

I propose that cognition is, most fundamentally, this primitive presence of something other than the subject to a perceiving subject - by which I mean nothing more than a being which can have some form of awareness of this presence of an 'other', as opposed to a non-sentient and non-perceiving being such as a stone, a thermometer, or a piece of iron, that is, beings capable of registering or reacting to the environment through a physical change but incapable of being aware of their environment as other than them.

I also propose that this kind of presence of an aliud (or object) to a subject is the most fundamental cognitive mode, without which no other mode of successful cognition would be possible, and that this most fundamental cognitive mode is what human knowing also essentially is. By the latter claim I mean the following: 1) notwithstanding the existence of vastly more evolved and sophisticated forms of knowledge with their own distinctive features (notably, propositional knowledge), all other forms of individual human knowing and of successful individual cognition are ultimately grounded in this most primitive form of knowing; 2) any embodied being capable of knowledge must be capable of this most basic form of it; 3) the most primitive and fundamental form of knowing is a form of perceiving; 4) all forms of individual knowing ultimately involve some form of perceiving, in the form either of sense-perception or (in rational cognitive subjects) of intellectual perceiving/seeing/grasping some intelligible object (e.g. grasping some property of an abstract object of mathematics such as an ideal triangle). ${ }^{5}$

Knowledge, I suggest, is therefore the result of a natural relationship between a perceiving being (the subject or I) and an object, merely understood here as not-I. There is a primitive openness of a perceiving being (precisely qua perceiving being) to the object which, in its most basic, sense-perceptual form, impinges in some way or another on the perceiver. It should be noted that

5 Establishing the ontological status of putative intelligible objects is of course a difficult and controversial enterprise. For present purposes, I hope it is sufficient to note that the phenomenology of thinking, say, an ideal triangle is that of presenting this triangle as other than me, whatever the more precise ontological status of an ideal triangle might be. I discuss ideal objects in more detail in Antognazza (forthcoming). 
this proposal is crucially different from McDowell's neo-Kantian account of experience as rational openness to independent reality - an account criticized by Ayers (2019, 74-85) from the point of view of a new empiricism. ${ }^{6}$ In Ayers as in my proposal, a key claim is that the most basic human cognition is nonconceptual, as is the case with other animals capable of perception.

What is distinctive of this relationship of a subject to an object is that, in the act of perceiving/knowing, there is a sui generis unification between perceiver and perceived, knower and known, with no gap between them. This sui generis contact is captured in a non-metaphorical way by the notion of intentional identity, that is, by a kind of identity between subject and object which is sharply different from a real or ontological identity. As I interpret it, G. E. Moore's "Refutation of Idealism" (1903) identifies the nature of knowing precisely with this "unique relation" of intentional identity, which holds between knower and known, and which consists in "'being aware of' or 'experiencing' something" $(1903,449)$ (although, in order to avoid a conflation between sensation and perception, taken in Reid's sense, I would not say, generically, 'being aware of' or 'experiencing' something but 'being aware of' or 'experiencing' an aliud). This is a relation which is in turn "perfectly distinct" from the relation of real identity which holds between a thing and its constituents (in Moore's example of a blue bead, the relation between me and blue as seen, as opposed to the relation between blue and the blue bead) (Moore 1903, 433-453). In brief, in the framework I am proposing, individual human knowledge is the intentional presence of an object (an aliud) to a subject. ${ }^{7}$

First-Person and Self-Knowledge

\subsection{Knowledge as First-Person}

The account proposed above supports the view (I claim) that knowledge is essentially or paradigmatically first-person, in the sense that it is a self's conscious awareness of being presented with a not-self. This not-self or not-I is obviously different in kind from 'self' or 'I': indeed, it is identified by its being not 'I' (its being aliud). It is a feature of the present account that there cannot be awareness of an aliud without some felt sense of distinction from this 'other', however primitive and inarticulate. It needs hardly to be said that the latter claim does not imply that all beings capable of awareness of an aliud as distinct from them have a concept of 'self', or 'I', or 'subject', or 'first person'. Still,

6 See McDowell 1994, 1995 and Sellars 1956/1963.

7 See Vanni Rovighi 1982, 19-30. 
they must sense or feel that they are distinct in order to perceive the presence of something 'other'.

I take it that this is in line with Michael Ayers's (2019, vi) claim that knowledge in its basic, paradigmatic form (or "primary knowledge") is something more

than the reliably caused true belief that many analytic philosophers have definitively identified as what constitutes knowledge. It is knowledge which is consciously knowledge. And without some primary knowledge some immediate and conscious cognitive contact with what is known no knowledge is possible. ${ }^{8}$

If epistemic externalism is the view that knowledge does not essentially - that is, primarily, fundamentally, paradigmatically - require awareness or consciousness of knowing in the sense outlined above, then this account is a rejection of externalism. ${ }^{9}$

It is crucial to stress, however, that this primitive awareness or consciousness of perceiving an object - in the terms of the KK principle, ${ }^{10}$ this knowing that one knows - may be logically second-order but is not an ontologically distinct factor in the act of knowing, produced by a psychologically second-order act of reflection. As one could put it, following Franz Brentano, perceiving $\mathrm{x}$ and awareness of perceiving $\mathrm{x}$ are the same act under different descriptions (Textor 2017, 6); or, as Ayers $(2019,63)$ notes in his phenomenological analysis of the direct cognitive contact with one's environment,

conscious perceptual knowledge is such that those that have it not only have perceptual knowledge of their environment, but also perceptual knowledge that and how they have that knowledge. They have that logically second-order knowledge without second-order reflection. They have what I have called 'primary knowledge', knowledge gained by being

8 The notion of "primary knowledge" is meant to identify what is central to knowledge in its basic, primary sense, without claiming that all instances of knowledge must exhibit all these features in order to qualify as knowledge in a secondary and derivative sense. See Ayers 2019, esp. vi, 27, 61-64, 115, 185, 195.

9 'Externalism' may of course mean quite different things. If it means that there are mental states whose "essence involves the world" (Williamson 1995, 563), this proposal supports it. Here, however, it is taken as the thesis that a subject cannot be aware of some of the necessary and sufficient conditions of knowing (see Ayers 2019, 164-185).

10 The KK principle "says that, if a subject knows that $p$, then that subject is in a position to know that they know that $p$ " (Greenough \& Pritchard 2009, 3). See Williamson 2000. 
evidently, self-consciously, in direct cognitive contact with the object of knowledge. ${ }^{11}$

In sum, the claim is not that one is always in a position to know that one knows, but that being in a position to know that one knows is central to knowledge in its primary sense. Furthermore, the claim is that the luminosity of "primary knowledge" does not imply an act of psychological reflection. In traditional scholastic terms, human conscious perceptual knowledge entails an implicit "I know, I perceive" in actu exercito (that is, in the very act by which one knows or perceives) and not in actu signato (that is, by a new mental act). Insofar as the $\mathrm{KK}$ principle requires that one is always in a position to know that one knows, or insofar as it implies a psychologically second-order act of reflection, the present proposal is compatible with a rejection of that principle. What the present proposal stresses, however, is that any rejection of the KK principle should not obscure that some knowledge is luminous and that without it there would be no knowledge at all.

\subsection{First-Person Knowledge versus Self-Knowledge}

Does the 'I' therefore immediately know itself in knowing the 'not-I'? Yes and no. 'Yes', if by knowing itself is meant the first-personal account of knowledge which I have proposed, and which entails (at least in its paradigmatic form) a subject consciously presented with an object. I agree, once again, with Ayers that in conscious perceptual experience, our "total experience is such that we are aware of the source of our knowledge" and such awareness "is central to what it is for the object to be directly 'presented' to the knower, rather than being merely 'represented' in thought or imagination" (Ayers 2019, 62). ${ }^{12}$

'No', if by knowing itself is meant a reflective act of knowledge in which the subject reflects on her act of cognition. This kind of self-knowledge is a higher, second-order kind of cognition. While being first-personal, the first acts of cognition immediately reveal the other rather than the cognitive self, precisely because the self (qua cognitive subject) is not an intentional object but the actualization of a primitive capacity of conscious awareness of an object. This follows from the view, defended above, that there is a properly cognitive activity, and a cognitive self, only when a felt self becomes aware of an aliud (an object) which is present in a way fundamentally different from the way

\footnotetext{
11 For a detailed defence of the thesis that "when we have (at least, pure or basic) perceptual knowledge, in general we know immediately that and how we have it" see esp. Ayers 2019, $34-69$.

By "source of our knowledge" is meant here the object known.
} 
in which the self's modes of being are present. In turn, this view seems to me in line with Elizabeth Anscombe's seminal paper on "The First Person" (1975) and her famous claim that ' $I$ ' does not refer, or is not a referring expression: Anscombe's claim draws attention to the fact that 'I' is not a kind of object at all, namely, it is not an object which happens to be myself as opposed to some other object, with the only difference of being reachable through some kind of internal perception.

I agree therefore with Aquinas that the first acts of cognition are directed not at ourselves but at the external, corporeal world. ${ }^{13}$ It seems to me, however, that Aquinas's restriction of the knowledge of our acts of thinking to higher, second-order cognition, in which the self becomes an intentional object of a reflective cognitive act, does not sufficiently acknowledge the essentially first-personal character of the first acts of cognition directed toward external things. The very character of 'otherness' (or 'externality') of these things implies that built into the first, object-directed acts of cognition is the awareness of a self which constitutes the unifying perspective from which what is phenomenologically given as 'other' is apprehended - a unifying perspective which, in turn, determines the mode of presentation under which this aliud is apprehended..$^{14}$

I draw inspiration, at this point, from another highly original (if lesser known) thirteenth century thinker, namely the Franciscan Peter John Olivi. As Dominik Perler shows, according to Olivi, there is a first-order knowledge which "comprises i) knowledge of one's own activities and ii) knowledge of oneself as the subject of these activities." (Perler 2019, 2) This first-order knowledge can be construed as an "experiential self-knowledge"15 which only tells us "about the existence of one's own activities and the underlying subject" (Perler 2019, 3, my emphasis). This is the kind of first-order knowledge which maps into what I have called the essentially first-personal character of knowledge. There is then also for Olivi a higher, second-order self-knowledge which is "theoretical self-knowledge" and which is "about the essence [that is, the metaphysical nature] of one's own activities and the underlying subject" (Perler 2019, 3, my emphasis; the square parenthesis is my addition).${ }^{16}$

\footnotetext{
13 See Perler 2017, 116-121 and Aquinas, Summa Theologiae I, Q. 87.

14 See Brewer 2011 and 2021 for the thesis that a person's position and orientation, and her particular perceptual circumstances are essential to the metaphysics of conscious perceptual experience itself.

15 See Olivi, Quaestiones in II librum Sententiarum, q. 76: "The first is by way of an experiential sense and, as it were, tactile [quasi tactualis]" (trans. by Perler).

16 See Olivi, Quaestiones in II librum Sententiarum, q. 76: "The second way of knowing oneself is gained through discursive reasoning by which one investigates the genera and the
} 
This distinction between first-order and second-order knowledge of the self seems to me an important, fruitful distinction, which I propose to cash out in terms of a distinction between 'first-person knowledge' and 'self-knowledge'. My proposal is that individual knowing in its paradigmatic form is essentially first-personal, that is, its object-directedness requires a built-in awareness of the self as the unifying perspective from which the aliud is apprehended. This proposal is therefore crucially different from Sosa's distinction between firstorder 'animal knowledge' and second-order 'reflective knowledge', according to which any knowing that one knows requires psychologically second-order reflection. ${ }^{17}$ As noted by Ayers, Sosa's "knowing that we know" is "available only to sufficiently reflective human beings, rather than an absolutely characteristic, built-in feature of ordinary, conscious, 'animal' perceptual knowledge." (Ayers 2019, 183). In a way similar to Ayers's basic perceptual knowledge, on my account, there is a sense in which knowing that one knows (in the form of a primitive, 'animal' awareness of the self which is confronted with an aliud) is a built-in feature of first-order knowledge as essentially first-personal. There is then a higher, second-order, reflective cognitive act in which the cognitive subject is capable of knowing herself, that is, is able of reflecting on herself and her actual states, standing attitudes, and dispositional properties, or even on her "being subject to the human condition" (Renz 2017a, esp. 9-12; here 11). This second-order kind of cognition is not a constituent of cognitive acts, which, as it were, comes for free; it is an achievement, the highest kind of which is arguably the morally significant achievement of Socratic self-knowledge (Renz $2017 \mathrm{~b}) .{ }^{18}$ As typical in matters of achievement, while we can gain some degree of success, we become also more aware of the limits of this success. It is certainly a limitation of our capacity for self-knowledge that the human mind will never be completely transparent to itself, ${ }^{19}$ but this acknowledgment of selfknowledge's limitation should not cause us to overlook the essentially firstpersonal character of knowing.

[specific] differences which one does not know in the first way of knowing" (trans. by Perler).

17 See Sosa 2001, 2007, and 2009. See Ayers 2019, 181-183.

18 The character of this second-order cognition as an achievement (or a "cognitive ascent") is stressed for instance by Aquinas. See Perler 2017, 118 (as noted by Perler, the expression "cognitive ascent" is borrowed from Pasnau 2002, 336-347).

19 Leibniz, for instance, provides one of the most compelling early examples of a philosophy of mind which takes fully on board the pervasiveness of unconscious thought. 


\section{Acknowledgments}

This discussion is part of a broader project which will be developed in Maria Rosa Antognazza, Thinking with Assent: Renewing a Traditional Account of Knowledge and Belief (forthcoming). Thanks are due to the Mind Association for supporting my project with a Mind Senior Research Fellowship. The remarks of section 1 of the article are inspired by the writings of Sofia Vanni Rovighi, in particular Vanni Rovighi 1962, 109-132 (esp. 109-118); 1963-1979, 347-374 (esp. 350-356); 1982, 19-24. I am greatly indebted to her insights. I am grateful for the helpful feedback I received from anonymous referees and from Maria Alvarez, Adrian Haddock, Howard Hotson, Naomi Osorio-Kupferblum, and Mira Magdalena Sickinger. Comments from participants to the book symposium organized by Naomi Osorio-Kupferblum (Vienna, 26-28 February 2020) and from participants to a workshop on self-knowledge organized by Johannes Roessler and Ursula Renz (Warwick University, 26-27 September 2019) have also been very helpful. Finally, my greatest debt is to Michael Ayers for many conversations on these matters and for his remarks on this article. Any shortcomings or misunderstandings are of course my sole responsibility.

\section{References}

Anscombe, G. E. M. 1975. "The First Person." In: Samuel Cuttenplan (ed.), Mind and Language, Wolfson College Lectures 1974, Oxford: Clarendon Press, 21-36.

Antognazza, Maria Rosa forthcoming. Thinking with Assent: Renewing a Traditional Account of Knowledge and Belief. Oxford: Oxford University Press.

Ayers, Michael 1991. Locke:The Arguments of the Philosophers, 2 vols. London: Routledge. Ayers, Michael 2019. Knowing and Seeing: Groundwork for a New Empiricism. Oxford: Oxford University Press.

Brewer, Bill 2011. Perception and Its Objects. Oxford: Oxford University Press.

Brewer, Bill 2021. "The Presidential Address: The Objectivity of Perception'." Proceedings of the Aristotelian Society 121, 1-20 (https://doi.org/10.1093/arisoc/aoaao18).

Greenough, Patrick and Pritchard, Duncan (eds.) 20o9. Williamson on Knowledge. Oxford: Oxford University Press.

Hume, David, A Treatise of Human Nature 1978 [1739-1740], edited by Lewis A. Selby-Bigge, and ed. revised by Peter H. Nidditch, Oxford: Clarendon Press.

Husserl, Edmund 1901/2nd ed. 1913. Logische Untersuchungen. Zweiter Band. Untersuchungen zur Phänomenologie und Theorie der Erkenntnis. I. Teil, Halle a.d.S.: Max Niemeyer. 
Maritain, Jacques 1948. Distinguer pour unir ou Les degrés du savoir. Revised and enlarged new edition, Paris: Desclée De Brouwer.

McDowell, John H. 1994. Mind and World, Cambridge, MA: Harvard University Press. Reissued with a new introduction, 1996.

McDowell, John H. 1995. "Knowledge and the Internal." Philosophy and Phenomenological Research 55, 877-893.

Moore, George Edward 1903. "The Refutation of Idealism." Mind 12, 433-453.

Olivi, Peter John 2014. Quaestiones in II librum Sententiarum, q. 76. In: Selbstbezug und Selbstwissen: Texte zu einer mittelalterlichen Debatte, edited by Dominik Perler and Sonja Schierbaum, Frankfurt am Main: Klostermann, 138-148.

Pasnau, Robert 2002. Thomas Aquinas on Human Nature: A Philosophical Study of Summa Theologiae I 75 -89. Cambridge: Cambridge University Press.

Perler, Dominik 2017. "Self-Knowledge in Scholasticism." In: Self-Knowledge: A History, edited by Ursula Renz, New York/Oxford: Oxford University Press, 114-130.

Perler, Dominik 2019. "What Is a Person? Olivi and the Franciscan Tradition." Handout for Conference on "The Summa Halensis: Philosophy and Reception", Oxford, 24 September 2019 .

Reid, Thomas 1997 [1764]. An Inquiry into the Human Mind on the Principles of Common Sense, edited by Derek R. Brookes, Edinburgh: Edinburgh University Press.

Renz, Ursula 2017a. "Introduction." In: Self-Knowledge: A History, edited by Ursula Renz, New York/Oxford: Oxford University Press, 1-18.

Renz, Ursula 2017b. "Self-knowledge as a Personal Achievement." Proceedings of the Aristotelian Society 117 (3), 253-272.

Renz, Ursula 2018. The Explainability of Experience: Realism and Subjectivity in Spinoza's Theory of the Human Mind. Oxford: Oxford University Press.

Renz, Ursula 2019. "Spinozist Cognitive Psychology: Spinoza's Concept of the Imagination." In:Konzepte derEinbildungskraft in der Philosophie, den Wissenschaften und den Künsten des 18. Jahrhunderts, edited by Rudolf Meer, Giuseppe Motta, and Gideon Stiening, Berlin: De Gruyter, 11-25.

Sellars, Wilfried 1956/1963. "Empiricism and the Philosophy of Mind." Minnesota Studies in the Philosophy of Science, vol. I. edited by Herbert Feigl and Michael Scriven, Minneapolis, MN: University of Minnesota Press, 253-329. [Originally presented at the University of London Special Lectures in Philosophy for 1956 as "The Myth of the Given: Three Lectures on Empiricism and the Philosophy of Mind". Reprinted in Science, Perception and Reality, London: Routledge \& Kegan Paul Ltd, 1963, 129-194, with additional footnotes.]

Sosa, Ernest 2001. "Human Knowledge, Animal and Reflective." Philosophical Studies $106(3), 193-196$.

Sosa, Ernest 2007. A Virtue Epistemology. Vol. I of Apt Belief and Reflective Knowledge. Oxford: Clarendon Press. 
Sosa, Ernest 2009. Reflective Knowledge. Vol. II of Apt Belief and Reflective Knowledge. Oxford: Clarendon Press.

Spinoza, Baruch 1925 [1st edition 1677]. Ethica Ordine Geometrico Demonstrata. In: Benedictus de Spinoza. Opera. Vol. 2., edited by Carl Gebhardt, Heidelberg: C. Winter.

Textor, Mark 2017. Brentano's Mind. Oxford: Oxford University Press.

Thomas Aquinas 1886-1887. Summa Theologiae. Textum Leoninum. Romae: Ex Typographia Senatus.

Vanni Rovighi, Sofia 1962. Elementi di Filosofia. Vol I. Brescia: La Scuola.

Vanni Rovighi, Sofia 1963-1979. Gnoseologia. Brescia: Morcelliana.

Vanni Rovighi, Sofia 1982. Istituzioni di Filosofia. Brescia: La Scuola.

Williamson, Timothy 1995. “Is Knowing a State of Mind?", Mind 104, 533-565.

Williamson, Timothy 2000. Knowledge and Its Limits. Oxford: Oxford University Press. 